УДК 378.015.3:374.7:[004:005.336.2]

DOI:

Світлана Ізбаш, кандидат педагогічних наук, доцент кафедри педагогіки та педагогічної майстерності Мелітопольський державний педагогічний університет імені Богдана Хмельнииького Сергій Пахомов, викладач кафедри готельно-ресторанної справи та системного аналізу Мелітопольський інститут державного та муніципального управління "КПУ”"

\title{
АНДРАГОГІЧНИЙ ПІДХІД ДО ФОРМУВАННЯ ПРОФЕСІЙНО-ПЕДАГОГІЧНОЇ КОМПЕТЕНТНОСТІ МАЙБУТНІХ УЧИТЕЛІВ ЗАСОБАМИ GООGLЕ-ТЕХНОЛОГІЙ
}

У статті розглянуто андрагогічний підхід до формування професійно-педагогічної компетентності y майбутніх учителів засобами Google-технологій. Проведено аналіз наукових праць вчених щзодо особливостей використання андрагогічного підходу у вищій иколі, формування професійно-педагогічної компетентності майбутніх вчителів та впровадження новітніх інформаційних технологій в освітній процес. Представлено зміст авторської програми навчальної дисципліни “Gооgle-технологї̈ як засіб формування професійно-педагогічної компетентності вчителя Нової украӥнської школи”, яка сприятиме усвідомленню майбутніми вчителями сучасних вимог до професії вчителя та формуванню базової професійно-педагогічної компетентності.

Ключові слова: навчання дорослих; андрагогічний підхід; колпетентність; професійно-педагогічна компетентність; бакалавр освіти; Google-технологї; Нова українська икола.

Табл. 1. Лім. 16.

Svitlana Izbash, Ph.D.(Pedagogy), Lecturer of the Pedagogy and Pedagogical Skills Department Melitopol Bohdan Khmelnitskiy State Pedagogical University

Serhiy Pakhomov, Lecturer of the Hotel and Restaurant Business and System Analysis Department Melitopol Institute of State and Municipal Management "Classical Private University"

\section{ANDRAGOLOGICAL APPROACH TO THE FORMING OF PEDAGOGICAL COMPETENCIES OF FUTURE TEACHERS BY MEANS OF GOOGLE TECHNOLOGIES}

In the article the peculiarities of the introduction of the andragical approach to the formation of vocational and pedagogical competence with the help of Google technologies are considered. The analysis of scientific works and theoretical sources of specialists who studied the peculiarities of the use of the andragogical approach in higher education, the formation of vocational and pedagogical competence of future teachers and the introduction of the latest information technologies in the educational process have been carried out. According to the analysis of popular science literature, it has been established that students studying at a high school belong to the adult population and their education should be carried out on the basis of an andragogical approach, and not according to generally accepted pedagogical principles. The comparison of the concepts of competency and competence is conducted. The key competences of the teacher of the New Ukrainian School in accordance with the Law of Ukraine "On Education" in 2017 are determined. According to the Law of Ukraine "On Education", in 2017, the content of the author's curriculum program "Formation of vocational and pedagogical competence of future bachelors of education by means of Google technologies" was developed and presented, aimed at developing the professional-pedagogical competence with the help of the latest information technologies. The curriculum is designed in accordance with the new requirements for teachers, which will reduce the gap between the level of professional training in higher education and the urgent need for highly skilled specialists at the New Ukrainian School.

Keywords: the adult education; an andragogical approach; competence; the vocational and pedagogical competence; a bachelor of education; Google-technology; New Ukrainian school.

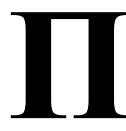

остановка проблеми. Сучасне суспільство потребуе підготовки вчителя нового типу, який здатен ефективно й мобільно реагувати на швидкоплинні процеси, що відбуваються в суспільстві, науці й техніці. Нові суспільні потреби вимагають, 3 одного боку, спрямування зусиль на підготовку вчителя Нової української школи, який має свободу творчості й розвивається професійно впродовж життя шляхом формальної, неформальної та інформальної освіти, уміє організувати людиноцентрований освітній процес, зорієнтований на формування всебічно розвиненої, здатної до критичного мислення цілісної особистості, патріота 3 активною позицією, новатора, здатного змінювати 


\section{АНДРАГОГІЧНИЙ ПІДХІД ДО ФОРМУВАННЯ ПРОФЕСІЙНО-ПЕДАГОГІЧНОЇ КОМПЕТЕНТНОСТІ МАЙБУТНІХ УЧИТЕЛІВ ЗАСОБАМИ GООGLЕ-ТЕХНОЛОГІЙ}

навколишній світ і працювати в команді, а 3 іншого боку, пошук і висвітлення сучасних інноваційних освітніх підходів до навчання дорослих та створення ефективного освітнього середовища з опануванням на практиці новітніми технологіями, методиками, формами, методами професійної діяльності з урахуванням потреб держави, регіонів, закладів освіти, суспільства, громадськості та індивідуальної траєкторії розвитку особистості педагога.

У зв'язку з висуненням нових вимог до педагогічних працівників актуалізується потреба модернізації професійної підготовки вчителя базової та профільної середньої школи у вищому навчальному закладі. Для розбудови ефективної системи професійної підготовки вчителя в умовах бакалаврату доцільно спиратися на ідеї теорії освіти дорослих та андрагогічного підходу, оскільки саме андрагогічний підхід забезпечує можливість створення такої моделі навчання, яка орієнтована на креативність, самомотивацію, саморозвиток майбутніх вчителів та закладає основи навчання упродовж життя. Традиційно модернізацію освіти асоціюють з педагогікою, але педагогічні принципи та підходи до змісту освіти у більшості зорієнтовані на навчання школярів і мало придатні для освіти студентів як дорослих учнів. Звідси виникає потреба конструювання освітнього процесу на принципах та засадах андрагогічного підходу.

Аналіз основних досліджені і публікацій доводить, що використання андрагогічного підходу у підготовці майбутніх вчителів вивчали О. Аніщенко, С. Архипова, В. Буренко, І. Воротникова, Л. Лук'янова, Н. Ничкало, О. Огієнко, С. Сисоєва, Л. Тимчук та ін. Проблему компетентнісного підхіду у вищій освіті досліджували М. Елькін, В. Луговий, О. Локшина, В. Овчарук, С. Павлютенков, Н. Побірченко I. Родигіна, Г. Селевко, В. Сименець, Л. Хоружа та ін. Впровадженням новітніх інформаційних технологій в освітній процес займалися Л. Білоусова, А. Гуржій, Р. Гуревич, Ю. Жидецький, Л.Жиліна,В.Злотник, А. Кудін,О. Падалка, О. Овчарук, I. Богданова, Ю. Господарик, О. Дмитриєва, М. Жалдак, О. Царенко.

Праці вчених свідчать, що в науці накопичено досить грунтовні знання з проблеми андрагогічного підходу, формування професійних компетентностей фахівців та використання інформаційних технологій в освітньому процесі, але досі залишаються поза увагою дослідників питання цілісного формування професійно-педагогічної компетентності майбугніх вчителів засобами Google-технологій на засадах андрагогічного підходу.
Мета статті - розкрити зміст формування професійно-педагогічної компетентності у майбутніх бакалаврів освіти за допомогою сервісів i програмного забезпечення Google на засадах андрагогічного підходу.

Завдання дослідження: 1) проаналізувати базові поняття дослідження: “андрагогічний підхід”, “компетентність”, “професійнопедагогічна компетентність”, “Google-технології навчання”; 2) розробити та представити програму навчальної дисципліни “Google-технології як засіб формування професійно-педагогічної компетентності вчителя Нової української школи”.

Процес освіти у вищій школі передбачає високий рівень самостійності студента: усвідомленість у навчанні, розуміння цінності та важливості навчання, самостійний пошук та аналіз наукової літератури, творчий та креативний підхіди до вирішення практичних завдань із застосуванням проаналізованих літературних джерел, що в свою чергу є принципами андрагогіки. Тобто при розгляді процесу навчання у вищій школі варто звернути увагу на андрагогічний підхід у навчанні.

Автори короткого термінологічного словника “Освіта дорослих” тлумачать андрагогічний підхід у навчанні як сукупність уявлень, які передбачають врахування особливостей процесу стимулювання, виховання, навчання й удосконалення дорослої людини під час професійної підготовки і перепідготовки, який інтегрує досвід індивідуального, творчого, особистісно зорієнтованого підходів [10,9].

Аспекти навчання дорослих у сучасній освіті за В. Вітюк базуються на провідних положеннях андрагогічного підходу, а саме:

- головна роль у власній освіті належить самому фахівцю;

- навчання має враховувати індивідуальні особливості педагога та відповідати його освітнім потребам і одночасно їх розвивати;

- у процесі навчання дорослих необхідно опиратися на їхнє прагнення до саморозвитку;

- навчальний процес - це спільна діяльність тих, хто навчається 3 тими, хто навчає.

О. Огієнко андрагогічний підхід тлумачить як: врахування та задіяність у процесі навчання особистісно-професійного досвіду студентів; конструювання змісту навчання у відповідності до потреб і інтересів тих, хто навчається; встановлення рівноправної статусної позиції викладача і студента, їх суб'єкт-суб'єктних відношень; діалогічна взаємодія учасників навчального процесу; створення сприятливих умов для самостійного і самоспрямованого 


\section{АНДРАГОГІЧНИЙ ПІДХІД ДО ФОРМУВАННЯ ПРОФЕСІЙНО-ПЕДАГОГІЧНОЇ КОМПЕТЕНТНОСТІ МАЙБУТНІХ УЧИТЕЛІВ ЗАСОБАМИ GООGLЕ-ТЕХНОЛОГІЙ}

навчання, активізації професійно-особистісного розвитку, надання їм більшої свободи й відповідальності [14, 338].

Андрагогічний підхід у системі освіти целеспрямований процес стимулювання, виховання, навчання й удосконалення дорослої людини під час професійної підготовки та перепідготовки, який інтегрує надбання індивідуального, творчого, особистісно зорієнтованого підходів [2, 8].

На думку Л. Ніколенко урахуванням андрагогічного підходу у навчанні відбувається за міждисциплінарними модулями. Провідна роль в його організації належить тому, хто навчається, тобто він $є$ активним учасником, одним 3 рівноправних суб'єктів навчального процесу. Атмосфера під час навчання дружня, неформальна, заснована на взаємній повазі, спільній роботі за підтримки й відповідальності всіх учасників навчальної діяльності, створюючи необхідні умови для розвитку та самореалізації особистості педагога [12, 284 - 287].

Швидкий темп оновлення та накопичення інформації в світі призводить до постійного оновлення змісту освіти та методів його подачі, що в свою чергу призводить до висунення нових вимог до знань, умінь та навичок правильно та зрозуміло подавати цю інформацію. Тому ніколи не втратить актуальності компетентнісний підхід в освіті. Для того щоб краще зрозуміти що таке компетентнісний підхід в освіті, розглянемо сутність поняття “компетенція", “компетентність” та тлумачення різних вчених, авторів, які досліджували ці поняття.

У великому тлумачному словнику сучасної української мови слово компетентність подано як поінформованість, обізнаність, авторитетність [3,560].

Відповідно до Закону України "Про освіту" (2017 p.) компетентність - це динамічна комбінація знань, умінь, навичок, способів мислення, поглядів, цінностей, інших особистих якостей, що визначає здатність особи успішно соціалізуватися, провадити професійну та/або подальшу навчальну діяльність [5].

Автор енциклопедії освіти В. Кремень зазначив, що компетентність у навчанні (лат. competentia - коло питань, в яких людина добре розуміється) набуває молода людина не лише під час вивчення предмета, групи предметів, а й за допомогою засобів неформальної освіти, внаслідок впливу середовища тощо. Так, C. Бондар тлумачить компетентність як загальну здатність і готовність до продуктивної діяльності, результативний блок, сформований через досвід, знання, вміння $[1,9]$. Український методист історичної освіти О. Пометун вказує, що компетентність - це спеціально структуровані набори знань, умінь, навичок і ставлень, що їх набувають у процесі навчання, які дозволяють людині “розв’ язувати незалежно від контексту (від ситуації) проблеми, характерні для певної сфери діяльності”. Відомий вчений І. Зязюн це поняття розглядає у соціально-педагогічному контексті і зазначає, що “компетентність як екзистенціональна властивість людини є продуктом ㄲï власної життєтворчої активності, ініційованої процесом освіти; як властивість індивіда вона існує в різних формах - як високий рівень умілості, як спосіб особистісної самореалізації (звичка, спосіб життєдіяльності, захоплення), як деякий підсумок саморозвитку індивіда, форма вияву здібностей тощо" [6, 17]. На думку О. Овчарук компетентність людини треба розуміти як спеціально структуровані набори знань, умінь, навичок і ставлень, що їх набувають у процесі навчання $[13,167]$. Професійна компетентність за I. Зязюном є підвалиною педагогічної майстерності, оскільки спрямованість і професійні знання становлять ту основу високого професіоналізму в діяльності, яка забезпечує цілісність системи, що самоорганізується [7, 25; 27]. Професійна компетентність Т. Мельник інтерпретується як базовий рівень, на основі якого формується готовність фахівця до професійної діяльності, його професіоналізм і педагогічна майстерність [11, 40]. Вчена С. Іванова під професійною компетентністю розуміє здатність фахівця від моменту початку своєї професійної діяльності на рівні визначеного державою певного стандарту відповідати суспільним вимогам професії шляхом ефективної професійної діяльності та демонструвати належні особисті якості $[8,110]$.

Заслуговує на увагу визначення професійної компетентності, запропоноване у словнику за редакцією академіка Н. Ничкало: “професійна компетентність - сукупність знань і умінь, необхідних для ефективної професійної діяльності, уміння аналізувати, передбачати наслідки професійної діяльності, використовувати інформацію” [4, 78].

Дискусія українських педагогів навколо питань “компетентність” в українській освіті дає підстави зробити висновок, що компетентність - це подальший особистісний і поведінковий прояв компетенцій. Компетентність може набуватися особистістю й розвиватися нею протягом життя за умови усвідомленої роботи над своїми навичками, здібностями, над удосконаленням своїх моделей поведінки, що включає одночасну 


\section{АНДРАГОГІЧНИЙ ПІХІД ДО ФОРМУВАННЯ ПРОФЕСІЙНО-ПЕДАГОГІЧНОӤ КОМПЕТЕНТНОСТІ МАЙБУТНІХ УЧИТЕЛІВ ЗАСОБАМИ GООGLЕ-ТЕХНОЛОГІЙ}

свідому відмову від стереотипів (стереотипних моделей поведінки і способів мислення) на підгрунті переосмислення особистісних потреб, цінностей і мотивацій.

З 2017 року відповідно нового Закону України “Про освіту” ключовими для Нової української школи визначено такі компетентності: спілкування державною мовою; спілкування іноземними мовами; математична грамотність; компетентності в природничих науках і технологія; інформаційно-цифрова компетентність; уміння навчатися впродовж життя; соціальні і громадські компетентності; підприємливість; загальнокультурна грамотність; екологічна грамотність та здорове життя [5]. У Типовій освітній програмі організації i проведення підвищення кваліфікації педагогічних працівників визначено базову професійно-педагогічну компетентність, яка включає обізнаність із новітніми науково обгрунтованими відомостями 3 педагогіки, психології, методик, інноватики для створення освітньо-розвивального середовища, що сприяє цілісномуіндивідуально-особистісному становленню дітей, здатність до продуктивної професійної діяльності на основі розвиненої педагогічної рефлексії відповідно до провідних ціннісносвітоглядних орієнтацій, вимог педагогічної етики та викликів школи $[15,2]$.

Впровадження інформаційно-комунікаційних технологій у навчально-виховний процес - це не гонитва за модою, а необхідність сьогодення. Для того, щоб формування інформаційної компетентності було ефективним, необхідні знання $з$ педагогіки: знання методів, форм, принципів навчання та інше. I навпаки: формування професійно-педагогічної компетентності майбутнього вчителя можна організувати за допомогою новітніх інформаційно-комунікаційних засобів. Таким чином, інформаційна та професійно-педагогічна компетентність майбутнього вчителя тісно пов'язані між собою. Крім того, аналіз проблем навчання студентів, зазначених у працях С. Шарова доводить, що у сучасних студентів недостатньо розвинуті компетентності самостійної навчальної діяльності; недостатньо враховуються індивідуальні особливості студентів як суб'єктів навчальновиховного процесу; іноді відсутня мотивація на виконання того чи іншого навчального завдання; недостатньо акцентується уваги на підготовку викладача, який складає завдання до самостійної роботи тощо [16,38]. Вирішенню означених проблем сприяє застосування Google-технологій у процесі формування професійно-педагогічної компетентності майбутніх учителів. Майбутній вчитель зможе одночасно підвищувати рівень своєї професійної компетентності відповідно до існуючих вимог суспільства та вдосконалювати навички використання новітніх інформаційних технологій у своїй діяльності. 3 цією метою нами розроблено програму навчальної дисципліни “Google-технології як засіб формування професійно-педагогічної компетентності вчителя Нової української школи" (табл. 1).

Таблиця 1 .

Програма навчальної дисципліни “Google-технології як засіб формування професійнопедагогічної компетентності в чителя Нової української школи”

\begin{tabular}{|c|c|}
\hline Тема & Компетентності \\
\hline \multicolumn{2}{|c|}{ Модуль 1. Google-технології у роботі вчителя Нової української школи } \\
\hline $\begin{array}{l}\text { Методика використання електронних } \\
\text { ресурсів Google для підготовки майбутніх } \\
\text { вчителів відповідно до реалізації Концепції } \\
\text { "Нова українська школа" }\end{array}$ & $\begin{array}{l}\text { інформаційна, цілепокладання, гностична, } \\
\text { технологічна, дидактична, організаційна, } \\
\text { конструктивна, рефлексивна, діагностична, гностична, } \\
\text { координаційна, коригувальна, оцінювальна }\end{array}$ \\
\hline Сервіс електронного листування Gmail & $\begin{array}{l}\text { інформаційна, організаційна, управлінська, } \\
\text { конструктивна, рефлексивна, гностична, } \\
\text { прогностична, коригувальна, оцінювальна }\end{array}$ \\
\hline $\begin{array}{l}\text { Сервіс для онлайн збереження документів } \\
\text { Google Drive }\end{array}$ & $\begin{array}{l}\text { інформаційна, гностична, організаторська, } \\
\text { рефлексивна, конструктивна, оцінна }\end{array}$ \\
\hline $\begin{array}{l}\text { Сервіс для роботи } 3 \text { документами онлайн } \\
\text { Google Docs }\end{array}$ & $\begin{array}{l}\text { інформаційна, конструктивна, організаторська, } \\
\text { проектувальна, управлінська, гностична, } \\
\text { проектувальна, коригувальна, оцінна }\end{array}$ \\
\hline Веб-сервіс для ведення блогів Blogger. & $\begin{array}{l}\text { інформаційна, дидактична, гностична, організаційна, } \\
\text { креативна, конструктивна, дослідницька, } \\
\text { проектуальна, коригувальна, оцінна }\end{array}$ \\
\hline $\begin{array}{l}\text { Сервіс для створення онлайн опитувань та } \\
\text { тестувань Google Forms }\end{array}$ & $\begin{array}{l}\text { інформаційна, конструктивна, проектувальна, } \\
\text { дослідницька, креативна, управлінська, діагностична, } \\
\text { прогностична, коригувальна, оцінна }\end{array}$ \\
\hline
\end{tabular}




\section{АНДРАГОГІЧНИЙ ПІДХІД ДО ФОРМУВАННЯ ПРОФЕСІЙНО-ПЕДАГОГІЧНОӤ КОМПЕТЕНТНОСТІ МАЙБУТНІХ УЧИТЕЛІВ ЗАСОБАМИ GООGLЕ-ТЕХНОЛОГЙ}

\begin{tabular}{|c|c|}
\hline & Продовження таблиці 1. \\
\hline $\begin{array}{l}\text { Сервіс для створення онлайн навчальної } \\
\text { платформи Google Classroom }\end{array}$ & $\begin{array}{l}\text { інформаційна, підприємницька, конструктивна, } \\
\text { проектувальна, організаційна, креативна, гностична, } \\
\text { координаційна, коригувальна, оцінна }\end{array}$ \\
\hline \multicolumn{2}{|c|}{$\begin{array}{l}\text { Модуль 2. Технологї̈ організації навчально-виховного процесу у роботі вчителя Нової } \\
\text { української школи }\end{array}$} \\
\hline $\begin{array}{l}\text { Технологія портфоліо як засіб оцінювання } \\
\text { навчальних досягнень учнів }\end{array}$ & $\begin{array}{l}\text { інформаційна, проектувальна, прогностична, } \\
\text { креативна, управлінська, рефлексія }\end{array}$ \\
\hline $\begin{array}{l}\text { Формування в учнів навичок критичного } \\
\text { мислення як запорука розвитку творчого } \\
\text { мислення. }\end{array}$ & $\begin{array}{l}\text { критичне мислення, цілепокладання, дидактична, } \\
\text { управлінська, гностична, організаційна, } \\
\text { конструктивна, проектувальна, креативна, } \\
\text { координаційна, коригувальна, оцінна }\end{array}$ \\
\hline $\begin{array}{l}\text { Формування комунікативних навичок, } \\
\text { використовуючи технологію кооперативного } \\
\text { навчання }\end{array}$ & $\begin{array}{l}\text { комунікативна, інформаційна, гностична, } \\
\text { проектувальна, організаторська, підприємницька, } \\
\text { креативна, критичне мислення }\end{array}$ \\
\hline $\begin{array}{l}\text { Технологія Веб-квест для формування } \\
\text { навичок роботи з електронною інформацією }\end{array}$ & $\begin{array}{l}\text { інформаційна, проектувальна, гностична, } \\
\text { організаторська, проектувальна, креативна, } \\
\text { управлінська, рефлексія, критичне мислення, } \\
\text { цілепокладання, координаційна, коригувальна, оцінна }\end{array}$ \\
\hline $\begin{array}{l}\text { Інтелект-карти як засіб формування } \\
\text { асоціативного мислення }\end{array}$ & $\begin{array}{l}\text { інформаційна, дидактична, проектувальна, гностична, } \\
\text { креативна, критичне мислення, проектувальна, } \\
\text { організаторська, координаційна }\end{array}$ \\
\hline \multicolumn{2}{|c|}{ Модуль 3. Організація освітнього простору взаємодії у роботі вчителя Нової української школи } \\
\hline $\begin{array}{l}\text { Педагогіка партнерства: сутність, основні } \\
\text { принципи }\end{array}$ & $\begin{array}{l}\text { комунікативна, організаторська, управлінська, } \\
\text { проектувальна, виховна, креативна, конструктивна, } \\
\text { діагностична, координаційна, коригувальна, оцінна }\end{array}$ \\
\hline $\begin{array}{l}\text { Організація ефективного і безпечного } \\
\text { освітнього } \\
\text { середовища }\end{array}$ & $\begin{array}{l}\text { організаційна, проектувальна, конструктивна, } \\
\text { виховна, управлінська, комунікативна, прогностична, } \\
\text { координаційна, коригувальна }\end{array}$ \\
\hline
\end{tabular}

Формуванняпрофесійно-педагогічної компетентності зацим курсомпередбачає: спільнудіяльність студента та викладача; пріоритет самостійного навчання; системність навчання; розвиток освітніх потреб; усвідомленість навчання. Ці провідні положення вивчення дисципліни відповідають принципам андрагогіки. Основним вектором вдосконалення рівня професійно-педагогічної компетентності майбутнього вчителя $\epsilon$ самовдосконалення шляхом постійної самоосвіти, накопичення знань та збагачення досвіду діяльності за допомогою засобів Google-технології.

Висновки. Аналіз праць вчених дає змогу стверджувати, що андрагогічний підхід поступово змінює психологію студента, підштовхує до самостійного, творчого та усвідомленого здобуття знань. Викладач виступає не в ролі інформатора, а перетворюється на організатора, консультанта дорослої людини, адже рівень кваліфікації та конкурентоспроможності сучасного спеціаліста залежить від рівня сформованості вмінь і навичок самостійної діяльності. Таким чином, удосконалення організації навчальної діяльності майбутніх учителів на засадах андрагогічного підходу і з використанням новітніх Google- технологій дозволить розвивати самостійність, активність, творчі здібності майбутніх учителів, забезпечить державузрілими висококваліфікованими педагогами 3 розвиненими професійнопедагогічними компетентностями, що у подальшому сприятиме швидкій адаптації до змін у професійній діяльності та самоосвіті впродовж життя.

\section{ЛІТЕРАТУРА}

1. Бондар С. П. Сутність та структура понять “компетенція" та “компетентність” у вітчизняній та зарубіжній педагогіці / С. П. Бондар // Наук. Часопис НПУ ім. М. П. Драгоманова. - Серія 17. - Теорія і практика навчання і виховання: зб. наук. праць. - К.: НПУ, 2007. - Вип. 6. - 267 с.

2. Буренко В.М. Андрагогічний підхід до професійної перепідготовки вчителя гуманітарного профілю: автореф. дис. на здобуття наук. ступеня канд. пед. наук: спец. 13.00.04 - Теорія і методика професійної освіти / В.М. Буренко. - К., 2005. - 21 с.

3. Великий тлумачний словник сучасної української мови / уклад. і голов. ред. В. Т. Бусел; 3 дод., доповн. та CD. - Ірпінь: ВТФ “Перун”, 2007. - C. 1472. 


\section{АНДРАГОГІЧНИЙ ПІДХІД ДО ФОРМУВАННЯ ПРОФЕСІЙНО-ПЕДАГОГІЧНОӤ КОМПЕТЕНТНОСТІ МАЙБУТНІХ УЧИТЕЛІВ ЗАСОБАМИ GООGLЕ-ТЕХНОЛОГІЙ}

4. Гончаренко С. У. Український педагогічний словник / С. У. Гончаренко. - Київ: Либідь, 1997. $-376 \mathrm{c}$.

5. Закон України “Про освіту” від 05.09.17. [Електронний ресурс]: Режим доступу. - http:// zakon3.rada.gov.ua/laws/show/2145-19

6. Зязюн І. А. Філософія поступу і прогнозу освітньої системи // Педагогічна майстерність: проблеми, пошуки, перспективи: монографія / I.А. Зязюн - К. $-2005 .-$ C. $10-18$.

7. Педагогічна майстерність: підручник / I. А. Зязюн, Л. В. Крамущенко, І. Ф. Кривонос та ін.; за ред. І. А. Зязюна. - 3-тє вид., допов. і переробл. - К.: СПД Богданова А.М., 2008. - 376 с.

8. Іванова С. В. Функціональний підхід до визначення професійної компетентності вчителя біології та організація її вдосконалення в закладі післядипломної освіти / С. В. Іванова // Вісник Житомирського державного університету ім. I. Франка. - 2008. - Вип. 42. - С. 106-110.

9. Ізбаш С. С. Реалізація творчих проектів у навчальному процесі сучасної школи [Електронний ресурс] / С. С. Ізбаш // Збірник наукових праць: Науковий вісник Мелітопольського державного педагогічного університету імені Богдана Хмельницького. Серія: Педагогіка. - 2010. - № 5. - С. 92-97. - Режим доступу до ресурсу: http://lib.mdpu.org.ua/nvsp/ 2010-05.html

10. Лук'янова Л.Б., Аніщенко О.В. Освіта дорослих: короткий етимологічний словник /Авт.упор. Лук'янова Л.Б., Аніщенко О.В. - К.; Ніжин: видавець ПП Лисенко М.М., 2014. - 108 с.

11. Мельник Т. Соціокультурна компетентність майбутнього словесника крізь призму суміжних наук // Вісник Луганського національного університету ім. Т. Г. Шевченка. Педагогічні науки. - 2010. - №. 22. - С. 209.

12. Ніколенко Л. Т. Андрагогічний підхід до навчання педагогів у системі післядипломної освіти // Стан і перспективи апробації шкільної навчальної літератури: матеріали Всеукр. наук.-метод. конф. - Кіровоград: КОІППО ім. В. О. Сухомлинського, 2009. - C. 284-287.

13. Овчарук О. Компетентності як ключ до оновлення змісту освіти // Стратегія реформування освіти в Україні: Рекомендації 3 освітньої політики. - К.: КІС. - 2003. - 296 с.

14. Огієнко О. І. Підготовка викладача вищої школи в умовах магістратури: андрагогічний підхід // Педагогічні науки: теорія, історія, інноваційні технології. - 2015. - № 6. - С. 336342.

15. Типова освітня програма організації і проведення підвищення кваліфікації педагогічних працівників закладами післядипломної педагогічної освіти. [Електронний ресурс]. Режим доступу: http://nus.org.ua/wp-content/ u p 1 o a d s / $2018 / 01 /$ P R O G R A M A _PIDGOTOVKY_NUSH.pdf

16. Шаров С. В. Самостійна робота як умова формування професійної компетентності майбутніх фахівців / С. В. Шаров // Сучасні тенденції розвитку української науки: матеріали Всеукр. наук. конф. (21-22 липня 2017 р., м. Переяслав-Хмельницький). - ПереяславХмельницький, 2017. - №. 5. - С. 35-38.

\section{REFERENCES}

1. Bondar S. P. (2007). Sutnist ta struktura ponjat "kompetencija" ta "kompetentnist" u vitchiznjanij ta zarubizhnij pedagogici [The essence and structure of the concepts of "competence" and "competence" in domestic and foreign pedagogy]. Nauk. Chasopis NPU im. M. P. Dragomanova. Serija 17. Theory and practice of education and upbringing: a collection of scientific works. Kyiv, NPU Publ., vol. 6, 267 p. [in Ukrainian].

2. Burenko, V.M. (2005). Andragogichnij pidhid do profesijnoï perepidgotovki vchitelja gumanitarnogo profilju [Andragogical approach to professional retraining of a humanitarian teacher]. Extended abstract of candidate's thesis. Kyiv, $21 \mathrm{p}$. [in Ukrainian].

3. Busel, V. T. (2007). Velykyi tlumachnyi slovnyk suchasnoi ukrayinskoi movy [Great Dictionary of Modern Ukrainian]. Irpin: Publishing House "Perun", 1472 p. [in Ukrainian]

4. Goncharenko, S. (1997). Ukrainskij pedagogichnij slovnik [Ukrainian Pedagogical Dictionary]. Kyiv, Libid Publ., 376 p. [in Ukrainian].

5. Zakon Ukrainy "Pro osvitu" vid 05.09.17 [The Law of Ukraine "On Education" of 05.09.17]. Retrieved from http://zakon3.rada.gov.ua/laws/show/ 2145-19

6. Zjazjun, I. A. (2005). Filosofija postupu i prognozu osvitnoi sistemy [Philosophy of progress and forecast of the educational system]. Pedagogical skills: problems, searches, perspectives: monograph. Kyiv, pp. 10-18. [in Ukrainian].

7. Zjazjun, I.A., Kramushhenko, L.V. \& Krivonos, I.F. (2008). Pedagogichna majsternist: pidruchnik [Pedagogical skill: textbook]. Kyiv, 376 p. [in Ukrainian].

8. Ivanova, S. V. (2008). Funkcionalnij pidhid do viznachennja profesijnoi kompetentnosti vchitelja biologii ta organizacija ii vdoskonalennja v zakladi pisljadiplomnoi osvity [Functional approach to the definition of professional competence of a teacher of biology and organization of its improvement in the 
institution of postgraduate education]. Scientific Journal of the Ivan Franko Zhytomyr: Vydvo ZhDU im. I. Franka, no. 42. pp. 106-110. [in Ukrainian].

9. Izbash, S. S. Realizatsiia tvorchykh proektiv u navchalnomu protsesi suchasnoi shkoly [Realization of creative projects in the educational process of modern school]. Scientific Journal of Melitopol State Pedagogical University of the Bogdan Khmelnitsky, Pedagogical sciences, no. 5, pp. 92-97. Retrieved from http://lib.mdpu.org.ua/nvsp/2010-05.html [in Ukrainian].

10. Lukjanova, L.B. \& Anishhenko, O.V. (2014). Osvita doroslih: korotkij etimologichnij slovnik [Adult Education: A Short Etymological Dictionary]. Nizhin, PP Lisenko M.M. Publ., 108 p. [in Ukrainian].

11. Melnik T. (2010). Sociokulturna kompetentnist majbutnogo slovesnika kriz prizmu sumizhnih nauk [Sociocultural competence of the future translator through the prism of related sciences]. Scientific Journal of the Taras Shevchenko Lugansk National University, Pedagogical sciences, no. 22, 209 p. [in Ukrainian].

12. Nikolenko, L.T. (2009). Andragogichnij pidhid do navchannja pedagogiv u sistemi pisljadiplomnoi osvity [An Andragogical Approach to Teaching Teachers in the Post-Graduate Education System]. Stan i perspektivi aprobacii shkilnoi navchalnoi literaturi: materiali Vseukrainskoi naukovo-metodychnoi konferentsii - The state and prospects of approbation of school textbooks: Proceedings of the All-Ukrainian Scientific-Methodical Conference. (pp. 284 - 287).
Kirovograd: KOIPPO im. V. Suhomlinskogo. [in Ukrainian].

13. Ovcharuk, O. (2003). Kompetentnosti jak kljuch do onovlennja zmistu osviti [Competence as a key to updating the content of education]. Education Reform Strategy in Ukraine: Educational Policy Recommendations, Kyiv, KIS Publ, vol. 296, 2 p. [in Ukrainian].

14. Ogienko, O. I. (2015). Pidgotovka vikladacha vishhoi shkoly v umovah magistraturi: andragogichnij pidhid [Preparation of a teacher of higher education in a master's degree: an andragological approach]. Pedagogical sciences: theory, history, innovative technologies, no. 6, pp. 336-342. [in Ukrainian].

15. Tipova osvitnja programa organizacii i provedennja pidvishhennja kvalifikacii pedagogichnih pracivnikiv zakladami pisljadiplomnoi pedagogichnoi osvity [A typical educational program for organizing and conducting professional development of pedagogical workers by institutions of postgraduate pedagogical education]. Retrieved from http:// nus.org.ua/wp-content/uploads/2018/01/ PROGRAMA_PIDGOTOVKY_NUSH.pdf

16. Sharov, S. V. Samostijna robota jak umova formuvannja profesijnoi kompetentnosti majbutnih fahivciv [Independent work as a condition for the formation of professional competence of future specialists]. Suchasni tendencii rozvitku ukrainskoi nauky: Materialy Vseukrainskoi naukovo-i konferentsii - Contemporary trends in the development of Ukrainian science: Proceedings of the All-Ukrainian Scientific Conference (pp. 35-38), no.5, Pereyaslav-Khmelnitsky. [in Ukrainian].

Стаття надійшла до редакції 30.03.2018

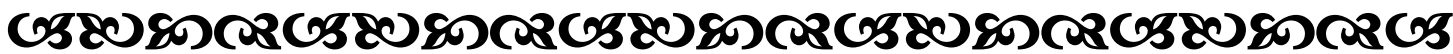

"ТІільки самоосвіта спроможна сбормувати справді ерудовану та всебічно розвинену особистість".

Жан-ЖаК Руссо

французький білософ, просвітник

“Майбутнє належить тим, хто вірить в красу своєї мрій”.

“Фобрі слова залишають в душах мюдей преқрасний слід. Вони пом'яқиують, втішають $і$ зиіляють серие того, хто ӥх чує”.

Блез Tаскаль

франиузький білософ, письменник

\section{G58080}

